\title{
JESYA
}

JURNAL EKONOMI 8 EKONOMI SYARIAH

Jurnal Ekonomi \& Ekonomi Syariah Vol 5 No 1, Januari 2022

E-ISSN : 2599-3410 | P-ISSN : 2614-3259

DOI : https://doi.org/10.36778/jesya.v5i1.634

\section{ANTHROPOMORFISM STRATEGY IN BUILDING LEGENDARY COFFEE BRANDS IN BANDUNG CITY}

\author{
Mutia Tri Satya, \\ STIE Ekuitas Indonesia \\ mutia.satya@gmail.com \\ Steffani Lule \\ Trisakti University Indonesia
}

\section{Abdul Fidayan \\ Sangga Buana University}

\begin{abstract}
Abstrak Purpose - The purpose of this paper is to develop and empirically test a research model examining the impact of Antropomorpishm strategy to create impact to build brand awareness and bring interest and to increase sales on 5 legend coffee brand in Bandung City. Design - The research model tested for 488 college students who regularly consumes coffee every day. Data were collected in Bandung using a self-administered onoine survey. Data analysis uses partial least swuares-structural equation modelling (PLS-SEM). Findings - The research found that if a brand uses the Anthropomorpism strategy, it can affect humans emotionally and make the brand closer to the user. The results show that the brand will become one with them because the brand has something unique and familiar to show. Research limitation/implication Through this research, it is hoped that legendary coffee can be used as input so that the product becomes a product that can innovate and be able to compete with other products even though it already has a brand as legendary coffee. Besides, it is also hoped that this research can be a reference source for future research that has similar topics and discussions. in order to be much better. Originality/value - The role of brand awareness is very important for SMEs so that their products are easily being recognize by consumers. The formation of a brand image can be done using anthropomorphism strategies. This paper contributes to the marketing literature by developing and empirically testing a research model Brand awareness, anthropomorphism, and to increase sales to coffee product in Bandung.
\end{abstract}

Keywords coffee; brand; SME; Antropomorphism; brand build; brand awareness.

\section{SUMMARY}

The development of an age so fast, so that strategies of brand or brand must adjust in line with the changes that occur. One of them is the Anthropomorphism strategy, which is widely used by well-known brands. As an example coffee memories which gave the name brand its brand with 


\section{JESYA}

JURKAL EKONOMI $\&$ EKONOMI SYARIAH

Jurnal Ekonomi \& Ekonomi Syariah Vol 5 No 1, Januari 2022

E-ISSN : 2599-3410 | P-ISSN : 2614-3259

DOI : https://doi.org/10.36778/jesya.v5i1.634

the name of "dine" so inviting taste humor generations melenial. Memorable coffee is top of mind for coffee milk lovers. Said memories to evoke the memory of the person who is not forgotten. Then the coffee of Janji Jiwa, which provides a poetic and philosophical tagline, namely coffee from the heart. Both coffee carrying the brand is simple but full of meaning that is easy to remember. This is one of the causes of consumers are interested to buy coffee this.

Not losing interestingly is the brand five copies legendary in Bandung, which consists of coffee Jabaco, Coffee Aroma, Coffee Tjian Lie Hong, Coffee Boat Diving and Malabar Coffee. But unfortunately, five coffee of the legendary still maintaining the brand and brand them as well as packaging that still survive are already tens of years. Then from the five coffee Legendary've had to do a change of the brand and are mainly in the packaging, so as not to lose the competition emergence of coffee new.

The role of the brand is very important for a business to be product so easily recognizable by consumers. The formation of the image of the brand can be done by using a strategy of anthropomorphism or anthropomorphism. Anthropomorphism or anthropomorphism describes the tendency to inspire the behavior of a real or a figment of the agent is not a human with the characteristics, motivations, intentions, or emotions that are similar to humans. Although very common, anthropomorphism has not has not always changed. Anthropomorphism is defined as the tendency to judge that non- human objects have characteristics, motivation, intentions, and emotions like humans (Epley, Waytz, and Cacioppo, 2007). "Trees were sad and hurt", so maybe that is imagined by us to act felling of wild trees in the forest. Humans have a tendency to judge that natural objects have emotions like humans. There is a feeling of not having the heart to imagine a "suffering " tree. Sometimes also people see no shape as the face of man on trees, clouds, hills, or on the rocks. By implementing an anthropomorphic strategy, it can make it easier for business actors to introduce their products. Like changing more contemporary packaging by using an anthropomorphic strategy. The purpose of research is that to build the brand of the 5 copies of the legendary in the city of Bandung. By using an anthropomorphic strategy. Research is important to do considering the brand became one of the value of sales for a product to make brand with a strategy of anthropomorphism is expected to be more attractive interest of consumers and further increase sales. In a study of this, we tried to dig more into the strategy of marketing to use anthropomorphism in building brand.

This research uses a qualitative approach. The nature ot this research is descriptive exploratory, meaning that we try to describe the characteristics of the fulfillment of the concept of anthropomorphism and also the brand in the context of the 5 Legendary coffee brands in Bandung. The strategy taken is a case study on the 5 Legendary coffee brands in Bandung. The object of research in this journal is 5 legendary coffees in Bandung. Based on the characteristics of the study descriptive qualitative, the researcher directly applicable as a researcher principal which did the research in direct, and collect the data using techniques of collecting the data in primary and secondary. The primary data carried out were in- depth interviews. Secondary data which is done is literature study. This research is limited to the audience's point of view, whether the audience sees the 5 Legendary coffees in Bandung has attracted attention or not and how is the personal closeness bulit by the 5 Legendary coffees in Bandung according to the audience. 


\section{JESYA}

JURNAL EKONOMI 8 EKONOMI SYARIAH

Jurnal Ekonomi \& Ekonomi Syariah Vol 5 No 1, Januari 2022

E-ISSN : 2599-3410 | P-ISSN : 2614-3259

DOI : https://doi.org/10.36778/jesya.v5i1.634

\section{BACKGROUND}

The development of an age so fast, so that strategies of brand or brand must adjust in line with the changes that occur. One of them is the Anthropomorphism strategy, which is widely used by well-known brands. As an example coffee memories which gave the name brand or its brand with the name of "dime" so inviting taste humor generations melenial. Memorable coffee is top of mind for coffee milk lovers. Said memories are used to evoke the memory of the person who is not forgotten. Then the coffee of Janji Jiwa, which provides a poetic and philosophical tagline, namely coffee from the heart. Both coffee carrying the brand is simple but full of meaning that is easy to remember. This is one of the causes of consumers are interested to buy coffee this.

Not losing interestingly is the brand five copies legendary in Bandung, which consists of coffee Jabaco, Coffe Aroma, Coffe Tjia Lie Hong, Coffee Kapal Selam, Malabar Coffee. But unfortunately, five copies of the legendary The still maintaining the brand and brand them as well as packaging that still survive are already tens of years. Then from the five coffee Legendary 've had to do a change of the brand and are mainly in the packaging, so as not to lose the competition emergence of new coffee. One of them is, as has been done by Janji Jiwa and Kopi Memories, which uses the Anthropomorphism strategy to attract more consumers' attention. The old school coffee, which was appointed by Legendary coffee, does have its own historical value, but it would be more interesting if the brand names were more varied. By lifting the concept Bandung tempo first, or the history of coffee the days before that may have been forgotten by a generation now.

The role of the brand is very important for SMEs to the product so easily recognizable by consumers. The formation of the image of the brand can be done by using a strategy anthropoorphism or anthropomorphism. Anthropomorphism or anthropomorphism describes the tendency to inspire the behavior of a real or a figment of the agent is not a human with the characteristics, motivations, intentions, or emotions that are similar to humans although very common, anthropomorphism has not always changed. Anthropomorphism is defined as the tendency to judge that non-human objects have characteristics, motivation, intentions, and emotions like humans (Epley, Waytz, and Cacioppo, 2007). " Trees were sad and hurt ", so maybe that is imagined by us to act felling of wild trees in the forest. Humans have a tendency to judge that natural objects have emotions like humans. There is a feeling of not having the heart to imagine a " suffering " tree. Sometimes also people see no shape as the face of man on trees, clouds, hills, or on the rocks. By implementing an anthropomorphic strategy, it can make it easier for SMEs to introduce their products. Like changing a more contemporary packaging by using anthropomorphic strategy. The purpose of research is that to build a brand or brand and image of the brand to SMEs by using strategies anthropomorphism.

Regarding the image of the brand, the image of the brand itself is representation of the overall perception of the brand and is formed of information and experience time ago to brand it. Anthropomorphism also can play a role important in estab formation of the image of the brand. Anthropomorphism is the identity of the brand, according to Andi M. Sadat (2009). The identity 


\section{JESYA}

JURNAL EKONOMI $\$$ EKONOMI SYARIAH

Jurnal Ekonomi \& Ekonomi Syariah Vol 5 No 1, Januari 2022

E-ISSN : 2599-3410 | P-ISSN : 2614-3259

DOI : https://doi.org/10.36778/jesya.v5i1.634

of the brand itself is a set of association of the brand that is unique that created by the constituent strategy brand. Relations identity brand with the image of the brand 's own, that identity is the introduction of the image. Identity brand delivered simultaneously with the sources of the information were other and then through media communication the signals is delivered to the consumer. These signals are treated as stimulus and are absorbed (apperception) by the senses and interpreted by consumers. The process of interpretation is done by associating with experience time ago and then interpreted. Process this is what is called a perception. It is based on this consumer perception that brand image is formed. Anthropomorphism mascot should be charismatic, familiar, and can be enjoyed. Inclusion quality this could be a concern consumer, pushing sales, and create the identification of the brand. Confidence and loyalty brand market can be associated with the image of anthropomorphism for the end consumer wants trusting and relate to the "appearance" personality brand (Klimchuk and Krasovec 2006).

In the field of marketing, anthropomorphism sure can impact positively on the behavior of the purchase of the consumer. Research History shows that anthropomorphism has the effect that positively on the behavior of consumers. Images of the product with the scheme of human (Aggarwal and McGill, 2007), the design of products with emotions humans (Smith, 2008) and the scheme of the baby (Miesler, 2011), influence positively on the evaluation of the product. Design products are anthropomorphic reduce the interest of consumers to replace their products (Chandler and Schwarz, 2010), and has the effect of which is positive on the preferences of consumers, and the number of sales (Landwehr, McGill, and Herrmann, 2011). Product design with the appearance of a human face, or having human intentions, reduces consumers' perceptions of risk, and increases the desire to use the product (Kim and McGill, 2011). In addition to the brand that is imaged own behavior such as humans, influencing consumers to behave according image of the brand (Aggarwal and McGill, 2012). Research is important to do considering the brand became one of the value of sales for a product to make brand with strategy Anthropomorphism is expected to increase sales such as that performed by actors attempt more. In a study of this, we tried to dig more into the strategy of marketing to use anthropomorphism in building brand.

\section{LITERATURE REVIEW \\ Anthropomorphism}

Anthropomorphism include attribution of the property of man on the object or agent non-humans are real or imaginary, where the attribution mentioned also includes the perception of the mind as thoughts are realized, metacognition, and intentions (Epley et al., 2007). Agent non- human that is real as animals, objects die, or nature. Meanwhile, imaginary non-human agents such as God, god, or Fairy. Humans give attribution of qualities of man on nature. Trees, mountains, rivers, and animals are respected and conceptualized as agents of anthropomorphism, not because of their physical benefits (Guthrie, 1995). Humans have a tendency towards anthropomorphism in trees and mountains, and according to previous studies, anthropomorphism towards trees is greater than anthropomorphism towards mountains (Norenzayan, Hansen, and Cady, 2008). Research History also shows that when confronted with the images of trees, participants study imagine leaves as hair, branches, twigs as a hand, and the sap as blood (Gebhard, Nevers, 
Billmann-Mahecha, 2004). Not only did they see the physical similarities between trees and humans, the participants also judged that trees have feelings. When asked to interpret a felled tree, participants imagine a tree that is sad and injured (Gebhard et al, 2004).

Depth anthropomorphism may vary, most people tend to be more anthropomorphism objects than others (Epley et al., 2007). One of the factors that make the difference that is effectance motivation, when assessing the object is not human, a person is motivated to interact as effectively and improve the ability to understand the actions of objects or agents that, reduce uncertainty and increase confidence in predicting the agent is in the future to come (Epley et al., 2007). According to Epley et al., (2007) cultural variables cause the level of anthropomorphism of society in various countries to be different. This is what makes anthropomorphism to the nature of consumers in Indonesia may different with consumers in other countries. In the culture of non-industrial (such as Indonesia), people tend to be close to nature and people more choose to interact with the creatures living are not human (Epley et al., 2007). Feeling connected is moral by nature already occurred since the first, the factors of cultural co-influence (Atran, and Medin, 2008).

\section{Brand}

Brand is the completeness of a product. So the product must have a brand. If you don't have it, it will be difficult for consumers to find the product again. American Marketing Association defines brand as follows : brand is a name, term, sign, symbol, design, or a combination of things that are have to identify the goods or service of one or a group of sellers to distinguish it from the products of competitors (Kottler and Keller, 2006 p . 258).

Adults of this almost all products by brand. In a fact products that previously did not need's brand, for example : salt, apples, wheat flour. Why do you need a brand? In addition to having a value if the brand is strong (brand equity), brand $\mathrm{j}$ uga beneficial for buyers and sellers (Kotler, 1998 h.198).

Brand benefits for buyers :

1. Tells the buyer something about the quality of the product

2. Help attract the attention of consumers to the products of the new that may be useful for the brand.

Benefits for sellers :

1. Make it easy for sellers to process orders and trace problems that arise.

2. Brand trade sellers provide protection law on distinctive product that is unique that without the protection of the law will be easily imitated by competitors.

3. Allows sellers attract a group of customers are loyal and profitable.

4. Helping sellers to segment the market.

State of the art

\begin{tabular}{|l|l|l|}
\hline No. & Anthropomorphism Brand Strategy & Source \\
\hline 1 & Anthropomorphism is a brand identity & Andi M. Sadat (2009) \\
\hline
\end{tabular}




\section{JESYA}

JURNAL EKONOMI \& EKONOMI SYARIAH

Jurnal Ekonomi \& Ekonomi Syariah Vol 5 No 1, Januari 2022

E-ISSN : 2599-3410 | P-ISSN : 2614-3259

DOI : https://doi.org/10.36778/jesya.v5i1.634

\begin{tabular}{|l|l|l|}
\hline 2 & $\begin{array}{l}\text { Anthropomorphism includes } \\
\text { the attribution of human property to objects }\end{array}$ & Epley et al., (2007) \\
\hline 3 & $\begin{array}{l}\text { Humans have an anthropomorphic tendency } \\
\text { towards trees and mountains }\end{array}$ & Norenzayan, Hansen, and Cady, (2008) \\
\hline 4 & $\begin{array}{l}\text { Need for cognition of perceived similarity } \\
\text { acquisition of alternative theory of experience, } \\
\text { norms and ideologies }\end{array}$ & $\begin{array}{l}\text { Nicholas Epley, Adam Wayt Z, John T. } \\
\text { Cacioppo, (2007) }\end{array}$ \\
\hline 5 & $\begin{array}{l}\text { Brand is a name, term, sign, symbol, design, or } \\
\text { a combination of those things are. }\end{array}$ & (Kottler and Keller, 2006 p. 258). \\
\hline 6 & $\begin{array}{l}\text { The brand aims to identify the goods or service } \\
\text { of one or a group of sellers to distinguish it } \\
\text { from the products of competitors }\end{array}$ & (Kottler and Keller, 2006 p. 258). \\
\hline 7 & Brands also benefit both buyers and sellers & (Kotler, 1998 p. 198). \\
\hline 8 & $\begin{array}{l}\text { Perceptions of mental capacities (competence, } \\
\text { trust and responsibility) }\end{array}$ & $\begin{array}{l}\text { Adam Wayt Z, Joy Heafner, Nicholas } \\
\text { Epley (2014) }\end{array}$ \\
\hline 9 & $\begin{array}{l}\text { Anthropomorphism and robots (people believe } \\
\text { that robot has human reasoning capabilities) }\end{array}$ & Brian R. Duffy (2003) \\
\hline 10 & $\begin{array}{l}\text { The ability to see market opportunities is an } \\
\text { advantage in terms of marketing }\end{array}$ & $\begin{array}{l}\text { Reijnders and Verstappen in Krake (2005 } \\
\text { p. 229) }\end{array}$ \\
\hline
\end{tabular}

\section{Roadmap}

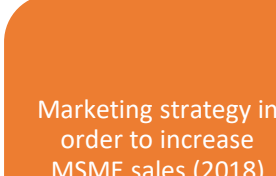

Establishment and

strengthening of

UMKM branding

(2019)

Place Branding (2019)

Renewal of the MSME

logo and brand (2019)

Compose brand

character SMEs 


\section{METHOD}

This research is a qualitative descriptive study. Research is conducted at the location of the business in order to obtain data using a source of primary data through interviews, observation and documentation. In the circuit has a supporting depth analysis, the research is also using also the data of secondary that is taken from the books, journals and others source were associated with anthropomorphism as a strategy of development of the brand.

The nature of this research is descriptive exploratory, meaning that we try to describe the characteristics of the fulfilment of the concept of anthropomorphism and also the brand in the context of the 5 Legendary coffee brands in Bandung. The strategy taken is a case study on the 5 Legendary coffee brands in Bandung. The object of research in this journal is 5 legendary coffees in Bandung. Based on the characteristics of the study descriptive qualitative, the researcher directly applicable as a researcher principal which did the research in direct, and collect the data using techniques of collecting the data in primary and secondary. The primary data carried out were in- depth interviews. Secondary data which is done is literature study. This research is limited to the audience's point of view, whether the audience sees 5 Legendary coffees in Bandung has attracted attention or not and how is the personal closeness built by 5 Legendary coffees in Bandung according to consumer perceptions.

1. Interview

The primary data obtained by one of them doing interviews. Types of interviews are conducted is in depth interview. In a study of this, we interviewed an audience which showed the brand of coffee 5 Legendary in Bandung by using the method of purposive sampling. The audience that was interviewed for data collection was five people. We record the conversation during an interview for then do the transcription of data.

2. Literature Study

The literature study in this research becomes secondary data. This secondary data can be collected by studying the literature, both documents and documentation. Researchers take the data secondary of journals, press releases, conferences, or sources other is directly explain the 5 coffee legendary in Bandung and anthropomorphism.

The TKT to be achieved is TKT 2

\section{RESULTS OF THE RESEARCH Respondent Profile}

In the description of the profile of respondents will explain about the identity respondent that includes the kind of sex and frequency of purchase. The results of the description regarding the identity of the respondent are as follows :

\section{Table 1 Profile of Respondents}


Jurnal Ekonomi \& Ekonomi Syariah Vol 5 No 1, Januari 2022

E-ISSN : 2599-3410 | P-ISSN : 2614-3259

DOI : https://doi.org/10.36778/jesya.v5i1.634

\begin{tabular}{|c|c|c|c|}
\hline \multicolumn{2}{|c|}{ Characteristics of Respondents } & Frequency & Percentage \\
\hline \multirow{3}{*}{ Type sex } & Man & 257 & 52.8 \\
\cline { 2 - 4 } & Women & 230 & 47.2 \\
\hline \multirow{4}{*}{ Purchase Frequency } & Several times in one day & 30 & 6.2 \\
\cline { 2 - 4 } & Two times in one week & 60 & 12.3 \\
\cline { 2 - 4 } & Rarely & 313 & 64.3 \\
\cline { 2 - 4 } & One time in a month & 33 & 6.8 \\
\cline { 2 - 4 } & One time a day & 51 & 10.5 \\
\hline
\end{tabular}

Source : Processed data

Based serving the data in Table 4.1, note that the respondents in the study is mostly large manifold sex male and rarely do purchase a brand five copies legendary in Bandung.

\section{Research Results}

Following are the results of descriptive data analysis and Confirmatory Factor Analysis using the SPSS 25 and Lisrel 8.80 programs, explained as follows :

\section{Description of Respondents' Answers}

The results of the analysis of statistics descriptive of the answers of respondents to each indicator research with criteria as follows :

Table 2 Value Criteria

\begin{tabular}{cc}
\hline Value Range $(\%)$ & Category \\
\hline $25-50$ & Low \\
$51-75$ & Enough \\
$76-100$ & High \\
\hline
\end{tabular}

Adapted from Arikunto, 2007

Table 3 Descriptive Analysis Results

\begin{tabular}{llll}
\hline Dimention and Aitem & Mean & Score & SD \\
\hline Appearance & $\mathbf{3 . 3 3}$ & $\mathbf{5 5 . 4 8}$ & $\mathbf{1 . 2 0}$ \\
1. This brand looks like a human & 3.16 & 52.67 & 1.43 \\
2. The brand is like life & 3.58 & 59.69 & 1.36 \\
3. This brand has a human- like appearance & 3.24 & 54.07 & 1.44 \\
Moral virtue & $\mathbf{4 . 2 3}$ & $\mathbf{7 0 . 5 0}$ & $\mathbf{0 . 9 8}$ \\
4. This brand can be trusted & 4.27 & 71.12 & 1.26 \\
5. The brand is honest & 4.31 & 71.83 & 1.21 \\
6. This brand has principles & 4.39 & 73.20 & 1.20 \\
7. This brand is very friendly to the environment & 4.06 & 67.69 & 1.24 \\
8. This brand represents honesty and comfort in the product & 4.13 & 68.75 & 1.18
\end{tabular}




\begin{tabular}{llll} 
9. This brand is for me very good & 4.22 & 70.40 & 1.15 \\
Cognitive experience & $\mathbf{4 . 0 3}$ & $\mathbf{6 7 . 1 8}$ & $\mathbf{1 . 1 2}$ \\
10. This brand involves a lot of thinking & 4.21 & 70.23 & 1.27 \\
11. The brand is made we can imagine all the things themselves & 3.76 & 62.70 & 1.37 \\
12. This brand seems to want to convey a feeling & 4.12 & 68.62 & 1.29 \\
Self Brand Congruity & $\mathbf{3 . 5 2}$ & $\mathbf{5 8 . 6 3}$ & $\mathbf{1 . 2 1}$ \\
$\begin{array}{l}\text { 13. The brand is in accordance with the } \\
\text { image that I hold about myself my own }\end{array}$ & 3.58 & 59.69 & 1.39 \\
14. The brand is in accordance with the image that I want other & & & \\
people hold about themselves me & 3.50 & 58.38 & 1.33 \\
15. Brand is describe myself I & 3.22 & 53.70 & 1.52 \\
16. This brand makes me easy to socialize & 3.77 & 62.77 & 1.42 \\
\hline Average & $\mathbf{3 . 8 5}$ & $\mathbf{6 4 . 0 9}$ & $\mathbf{1 . 3 2}$ \\
\hline
\end{tabular}

Based on Table 4. 2, obtained values average dimension highest is Moral Virtue is at 4.23. According to the respondents the brand five copies Legendary own moral virtue that high is a brand that is honest, can be trusted, very friendly to the environment, very nice, and has a principle. While the lowest dimension assessed by respondents is Appearance. Where respondents do not agree that the five Legendary coffee brands look alive and like humans. With such a brand on a five coffee Legendary need to do updates so that more lives. That can be by adding a pattern or image that is more fresh and alive so as to attract the interest of consumers.

\section{Results of CFA Analysis \\ Construct Validity and Reliability}

Validity concerns the level of accuracy that is achieved by an indicator in judging something or inaccurate measurements on what are supposed to be measured. While reliability is a measure of the consistency of the internal of the indicators of a construct that indicates the degree to which each indicator that indicates a construct that is common. Because the indicator is multidimensional, the validity test of each latent variable/construct will be tested by looking at the loading factor of the relationship between each observed variable and the latent variable. Meanwhile, reliability was tested with construct reliability and variance extracted. From the results of the processing of the data obtained the results as presented in following this.

\section{Table 3 Validity Test Results}

\begin{tabular}{lc}
\hline \multicolumn{1}{c}{ Dimention and Aitem } & $\lambda$ \\
\hline Appearance & 0.80 \\
1. This brand looks like a human & 0.74 \\
2. The brand is like life & 0.77 \\
3. This brand has a human- like appearance & 0.72 \\
Moral virtue & 0.80 \\
4. This brand can be trusted & 0.76 \\
5. The brand is honest & 0.74 \\
6. This brand has principles &
\end{tabular}




\section{JESYA}

JURNAL EKONOMI 8 EKONOMI SYARIAH

Jurnal Ekonomi \& Ekonomi Syariah Vol 5 No 1, Januari 2022

E-ISSN : 2599-3410 | P-ISSN : 2614-3259

DOI : https://doi.org/10.36778/jesya.v5i1.634

8. This brand represents honesty and comfort in the product

0.83

9. This brand is for me very good

0.79

Cognitive experience

$\begin{array}{ll}\text { 10. This brand involves a lot of thinking } & 0.73\end{array}$

11. The brand is made we can imagine all the things themselves $\quad 0.77$

$\begin{array}{ll}\text { 12. This brand seems to want to convey a feeling } & 0.79\end{array}$

Self Brand Congruity

13. The brand is in accordance with the image that I hold about myself my own $\quad 0.87$

14. The brand is in accordance with the image that I want other people hold about $\begin{array}{ll}\text { themselves me } & 0.84\end{array}$

$\begin{array}{ll}\text { 15. Brand is describe myself I } & 0.80\end{array}$

$\begin{array}{ll}\text { 16. This brand makes me easy to socialize } & 0.70\end{array}$

Source : primary data, processed.

Based on Table 4. 3 it can be known that on all the indicators declared invalid. It is indicated by the value of the loading factor which is obtained by each indicator is more than 0.5 .

Having known the validity of the construct, then the next is find out the reliability of the constructs that. Testing the reliability of this use of the construct reliability or variance extracted by the formula as follows

$$
\begin{aligned}
& \text { Construct Reliability }=\frac{\left(\sum \text { Std.Loading }\right)^{2}}{\left(\sum \text { Std. Loading }\right)^{2}+\sum \varepsilon_{j}} \\
& \text { Variance Extracted }=\frac{\sum\left[\text { Standardize Loading }{ }^{2}\right]}{\sum\left[\text { Standardize Loading }{ }^{2}\right]+\sum \varepsilon_{j}}
\end{aligned}
$$

In general, the value of the limit which is used to assess a level of reliability that can be accepted is if the value of the construct reliability more substantial than 0.7 or the value of variance extracted more substantial than 0.5 . Here it is the result of the test of reliability.

Table 4. 4 Reliability Test Results

\begin{tabular}{lll}
\hline Dimention & CR & AVE \\
\hline 1. Appearance & 0.81 & 0.59 \\
2. Moral virtue & 0.90 & 0.60 \\
3. Cognitive experience & 0.81 & 0.58 \\
4. Self Brand Congruity & 0.88 & 0.65 \\
\hline
\end{tabular}

Source : primary data, processed .

The results of the instrument reliability test with construct reliability show that the instrument is reliable, which is indicated by the value of the construct reliability is greater than 0.7 and the extracted variance is greater than 0.5. By thus, all the indicators have validity are high in measuring Brand Antropomorphism. 


\section{Goodness of Fit}

In the model of measurement parameters estimated in together and must meet the demands of fit model, by because it is a model to be based on the theory of the strong. The results of estimation and fit model by using a program application lisrel 8.80 can be seen at the bottom of this :

Table 4.5 Goodnes Of Fit Results

\begin{tabular}{|c|c|c|c|}
\hline Criteria & Result & Cut - off Value & Model Evaluation \\
\hline CMIN / DF & 3.6389 & $\leq 2.00$ & Not Fit \\
\hline RMSEA & 0.075 & $\leq 0.08$ & Good Fit \\
\hline GFI & 0.91 & $\geq 0.90$ & Good Fit \\
\hline AGFI & 0.88 & $\geq 0.90$ & Marginal Fit \\
\hline TLI / NNFI & 0.98 & $\geq 0.90$ & Good Fit \\
\hline CFI & 0.98 & $\geq 0.90$ & Good Fit \\
\hline IFI & 0.98 & $\geq 0.90$ & Good Fit \\
\hline
\end{tabular}

Table 4.5 shows that $\geq 5$ criteria for goodness of fit has meet the cut-off value, things that indicate the results of the evaluation showed a good model. It explains that the model used in the study have resulted in the level of estimation are expected. Thus, this model is a good and feasible model to explain Brand Anthropomorphism.

\section{Contribution of Appearance Dimensions, Moral virtue, Cognitive experience and Self Brand Congruity}

Contributions Dimensions Appearance, Moral virtue, Cognitive experience and Self Brand Congruity in measuring Brand Anthropomorphism can be seen through the picture at the bottom of this : 


\section{JESYA}

JURNAL EKONOMI 8 EKONOMI SYARIAH

Jurnal Ekonomi \& Ekonomi Syariah Vol 5 No 1, Januari 2022

E-ISSN : 2599-3410 | P-ISSN : 2614-3259

DOI : https://doi.org/10.36778/jesya.v5i1.634

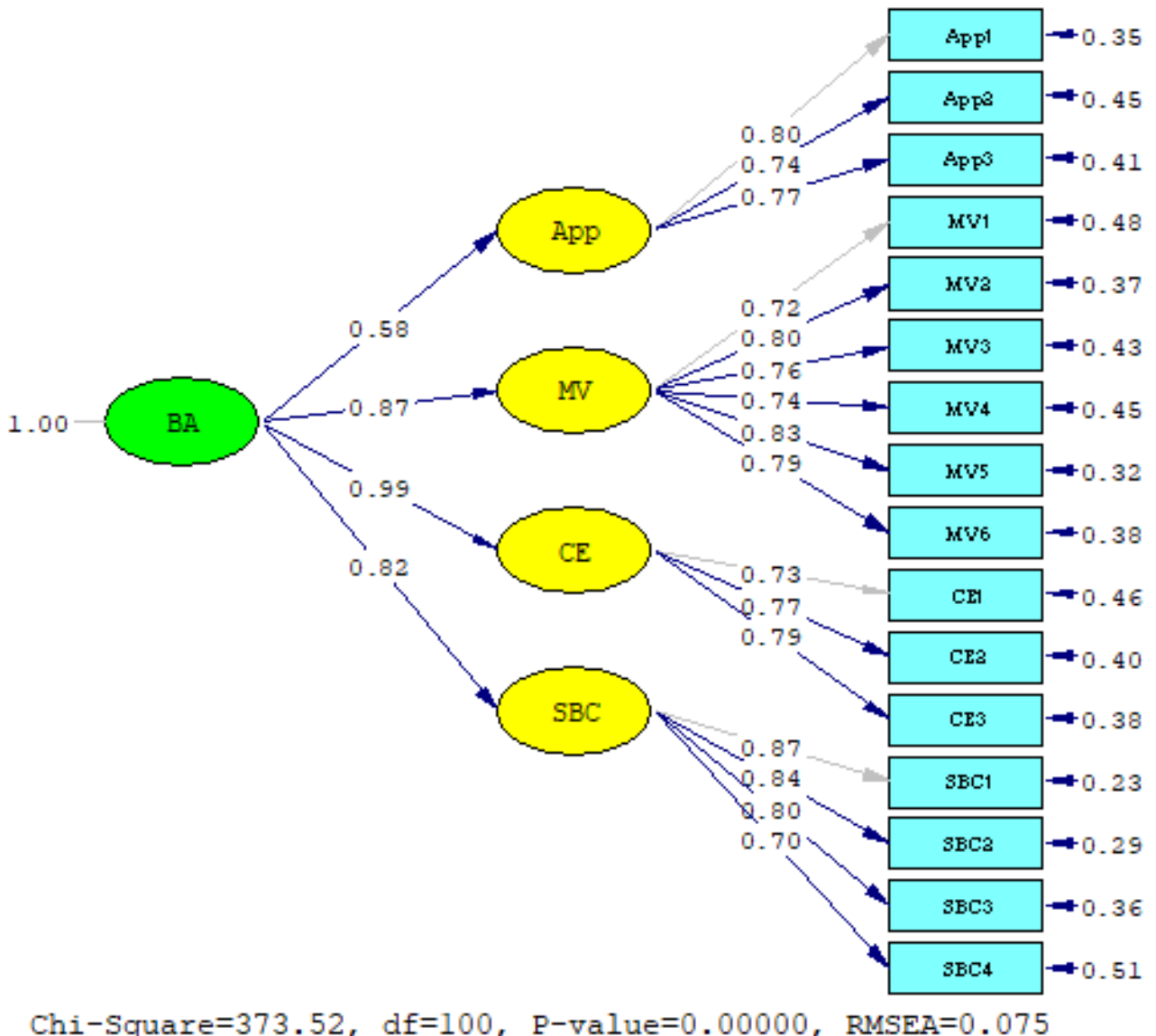

Based on the results of the model measurements in the above in mind that the value of the loading highs are in the dimension Cognitive experience. It is meant dimensions Cognitive experiences is able to measure Brand anthropomorphism most high compared to the dimensions of the Appearance, Moral virtue, and Self Brand Congruity.

Based on the results of the descriptive analysis, an average of 4.03 is produced in the cognitive experience dimension. This value is quite high which indicates that the 5 Legendary coffee brands in Bandung have a fairly high anthropomorphism.

\section{CONCLUSION :}

In the field of marketing, anthropomorphism is believed to have a positive effect on consumer purchasing behavior. Previous research has shown that anthropomorphism has a positive influence on consumer behavior. Product images with human schemes (Aggarwal and McGill, 2007), product designs with human emotions (Smith, 2008) and baby schemes (Miesler, 2011), have a positive effect on product evaluation. Anthropomorphic product design reduces consumer interest in replacing the product (Chandler and Schwarz, 2010), and has a positive effect on 


\section{JESYA}

JURNAL EKONOMI $\$$ EKONOMI SYARIAH

Jurnal Ekonomi \& Ekonomi Syariah Vol 5 No 1, Januari 2022

E-ISSN : 2599-3410 | P-ISSN : 2614-3259

DOI : https://doi.org/10.36778/jesya.v5i1.634

consumer preferences, and the number of sales (Landwehr, McGill, and Herrmann, 2011). This research is important to do considering that the brand is one of the selling points for a product by creating a brand with an Anthropomorphism strategy which is expected to increase sales as is done by other business actors.

Anthropomorphism includes the attribution of human property to real or imaginary non-human objects or agents, where the attribution also includes thought perceptions such as conscious experience, metacognition, and intention (Epley et al., 2007). Brand is the completeness of a product. So the product must have a brand. If you don't have it, it will be difficult for consumers to find the product again. The American Marketing Association defines a brand as follows: a brand is a name, term, sign, symbol, design, or a combination of these that aims to identify the goods or services of a person or group of sellers to distinguish them from competing products (Kottler and Keller, 2006 p. 258).

This research uses a qualitative approach. The nature of this research is descriptive exploratory, meaning that we try to describe the characteristics of the fulfillment of the concept of anthropomorphism and also the brand in the context of the 5 Legendary coffee brands in Bandung. The strategy taken is a case study on the 5 Legendary coffee brands in Bandung. The object of research in this journal is 5 legendary coffees in Bandung. Based on the characteristics of qualitative descriptive research, the researcher immediately acts as the main researcher who carries out the research process directly, and collects data using primary and secondary data collection techniques. The primary data carried out were in-depth interviews. Secondary data which is done is literature study. This research is limited to the audience's point of view, whether the audience sees the 5 Legendary coffees in Bandung has attracted attention or not and how is the personal closeness built by the 5 Legendary coffees in Bandung according to the audience.

The results of descriptive data analysis and Confirmatory Factor Analysis using SPSS 25 and Lisrel 8.80 programs, obtained that the highest average dimension value is Moral Virtue, which is 4.23. According to respondents, the five Legendary coffees have high moral virtue, namely brands that are honest, trustworthy, very friendly to the environment, very good, and have principles. While the lowest dimension assessed by respondents is Appearance. Where respondents do not agree that the five Legendary coffee brands look alive and like humans. Thus, the brands on the five Legendary coffees need to be updated to make it more alive. Namely, you can add a more fresh and lively image or style so that it can attract consumer interest. Based on the results of the measurement model above, it is known that the highest loading value is in the cognitive experience dimension. This means that the Cognitive Experience dimension is able to measure Brand Anthropomorphism the highest compared to the dimensions of Appearance, Moral virtue, and Self Brand Congruity. Based on the results of the descriptive analysis, an average of 4.03 is produced in the cognitive experience dimension. This value is quite high which indicates that the 5 Legendary coffee brands in Bandung have a fairly high anthropomorphism. 


\section{JESYA}

JURNAL EKONOMI 8 EKONOMI SYARIAH

Jurnal Ekonomi \& Ekonomi Syariah Vol 5 No 1, Januari 2022

E-ISSN : 2599-3410 | P-ISSN : 2614-3259

DOI : https://doi.org/10.36778/jesya.v5i1.634

\section{ROLE OF PARTNERS:}

The partners in question are respondents in the study. The respondents give a role that is very meaningful for the study, ie with m emberikan the data and provide information related to the development of coffee kekninian which can be used as input for the Five Coffee Legendary Bandung so it can be used as a reference in the study.

\section{RESEARCH IMPLEMENTATION CONSTRAINTS:}

Constraints research is brand awareness which owned 5 Coffee legendary in Bandung (Coffee Jabaco, Coffee Aroma, Coffee Tjia Lie Hong, Coffee Boat Diving and Coffee Malabar) less inherent among generations of young who are the respondents so that the respondents tend to give answers with limited knowledge.

\section{RESEARCH FOLLOW UP PLAN:}

A plan that needs to be done by 5 Coffee legendary in Bandung ( Coffee Jabaco, Coffee Aroma, Coffee Tjia Lie Hong, Coffee Boat Diving and Coffee Malabar) addalah with $\mathrm{m}$ arouses strategy $\mathrm{y}$ an $\mathrm{g}$ contemporary and more updates that are not forgotten and still be legendary coffee in the city of Bandung.

\section{BIBLIOGRAPHY}

Aggarwal, P., \& McGill, AL, 2007. Is that car smiling at me? Schema congruity as a basis for evaluating anthropomorphized products, Journal of Consumer Research, 34: 468-479.

Aggarwal, P., \& McGill, AL, 2012. When brands seem human, do humans act like brands? Automatic behavioral priming effects of brand anthropomorphism, Journal of Consumer Research, 39 (2): 307-323.

Atran, S., \& Medin , D. L. , 2008 . The native mind and the cultural construction of nature. Cambridge, MA: MIT Press.

Carson, DJ (19 95). The Evolution of Marketing in Mall Firms, European Journal of Marketing, Vol. 19 No. 5, pp 7-16.

Chandler, JJ, \& Schwarz, 2010. Use does not wear ragged the fabric of friendship: thinking of objects as alive makes people less willing to replace them. Journal of Consumer Psychology, 20: 138-145.

Epley, N., Waytz , A., \& Cacioppo, JT, 2007. On seeing human: A three- factor theory of anthropomorphism, Psychological Review, 114 (4): 864-886.

Gebhard, U., Nevers, P., Billmann-Mahecha , E., 2004. Moralizing Trees: Anthropomorphism and identity in children's relationships to nature. Identity and the natural environment: the psychological significance of nature. Edited by Clayton, S. \& Opotow, S. The MIT Press, London, England

Guthrie, S., 1995. Faces in the clouds: A new theory of religion. Oxford University Press

Kakisina , Stephen (2002). Small and Medium Ente rprises Development Policies in Papua, Journal of Economics and Business , Dian Economist i , Vol VIII, No. 3 things 429-442. 


\section{JESYA}

JURNAL EKONOMI 8 EKONOMI SYARIAH

Jurnal Ekonomi \& Ekonomi Syariah Vol 5 No 1, Januari 2022

E-ISSN : 2599-3410 | P-ISSN : 2614-3259

DOI : https://doi.org/10.36778/jesya.v5i1.634

Kell er, KL (2003). Strategic Brand Mana gement: Building, Measuring and M anaging Brand Equity, 2 nd ed., Englewood Cliffs, NJ: Prentice-Hall, Inc.

Kim, S. , \& McGill AL, 2011. Gaming with Mr. Slot or gaming the slot machine? Power, anthropomorphism, and risk perception, Journal of Consumer Research, 38: 1-15

Kotler, P , (1998). Marketing Management: Anal ysis, Planning, Implementation, Control, 8 th ed. Englewood Cliff, NJ: Prentice Hall.

Krake , Frank B.GJM , (2005). Successful Brand Man agement in SMEs: A New Theory and Practical Hints, The Journal of PROD UCT and Management, vol.14, pp. 233-228.

Landwehr, JR, McGill AL, \& Herrmann, A., 2011. It's got the look: the effect of friendly and aggressive "facial" expressions on product liking and sales, Journal of Marketing, 75: 132-146.

Miesler, L. , 2011. Imitating human forms in product design: How does anthropomorphism work, when does it work, and what does it affect? Dissertation. University of St. Gallen. Switzerland

Norenzayan , A., Hansen, IG, \& Cady, J., 2008. An angry volcano? Reminders of death and anthropomorphizing nature, Social Cognition, 26 (2): 190-197.

Smith, A., 2008. King III reduces the opportunity for corporate governance shortcuts. ContinuitySA .

Ayu, SP, 2020. ANTROPOMORPHISM BRAND: DIGITAL CAMPAIGN TO PREVENT COVID-19 BY TRAVELOKA . Journal of Communication Science Vol. 10, No.2. 